\title{
脳卒中の診療態勢
}

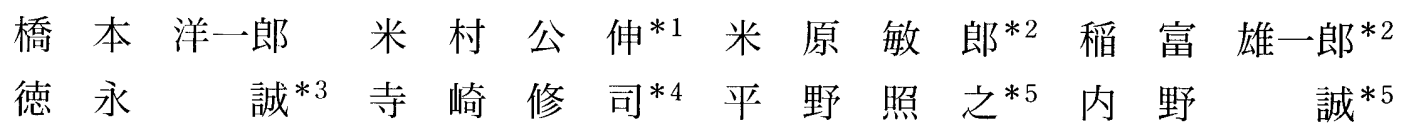

\section{Stroke Management System}

by

Yoichiro Hashimoto, M.D., Kiminobu Yonemura, M.D. ${ }^{* 1}$, Toshiro Yonehara, M.D. ${ }^{* 2}$, Yuichiro Inatomi, M.D. ${ }^{* 2}$, Makoto Tokunaga, M.D. ${ }^{* 3}$, Tadashi Terasaki, M.D. ${ }^{* 4}$, Teruyuki Hirano, M.D. ${ }^{* 5}$, and Makoto Uchino, M.D. ${ }^{* 5}$ from

Department of Neurology of Kumamoto City Hospital, ${ }^{* 1}$ Department of Strokology of Kumamoto City Hospital, ${ }^{* 2}$ Department of Neurology, Stroke Center, Saiseikai Kumamoto Hospital, ${ }^{* 3}$ Department of Neurology of National Kumamoto Hospital (presently, Department of Neurology, Kumamoto Kinou Hospital), ${ }^{* 4}$ Department of Neurology, Kumamoto Red Cross Hospital, and ${ }^{*}$ Department of Neurology, Graduate School of Medical Sciences, Kumamoto University

Stroke is a medical emergency and time after onset is brain function. Therefore, it is essential to make every effort to develop all urgent correspondence full system for acute stroke. In 1997, NINDS (National Institute of Neurological Disorders and Stroke) presented the response time after the arrival of a stroke patient to a hospital by emergency, followed by AHA (American Heart Association) their a guideline 2000. The goal should be to (1) perform an initial patient evaluation within 10 minutes of arrival in the emergency department, (2) notify the stroke team within 15 minutes of arrival, (3) initiate a CT scan within 25 minutes of arrival, (4) interpret the CT scan within 45 minutes of arrival, (5) ensure a door-to-drug (needle) time of 60 minutes from arrival, and (6) transfer the patient to an inpatient setting within 3 hours of arrival. Should the patient meet the criteria for thrombolysis, quick access to stroke expertise within 15 minutes and to neurosurgical expertise within 2 hours of hospital arrival is recommended.

Stroke patients have longer length of hospital stay. Stroke management is needed for the where team, (1) home doctor, (2) acute hospital, (3) rehabilitation hospital, and (4) care house. After the introduction of a clinical pathway dedicated for acute ischemic stroke of varying severity in 1995, the average length of hospital stay of both stroke and non-stroke patients declined in our hospital.

Rehabilitation in the recovery stage can be done in the specialized rehabilitation hospitals within Kumamoto due to inter-hospital cooperation. Our acute stroke team can concentrate on the treatment of stroke in the acute stage (within 1 $\sim 4$ weeks from the onset). We have been developing this stroke management system based on an acute stroke unit with referral to a rehabilitation unit in another hospital (inter-hospital referral model) in contrast to the conventional system with a combined acute and rehabilitation stroke unit in a single hospital (intra-hospital referral model). Eight-hundred and six patients (459 male, 347 female, $71.0 \pm 12.2$ years-old) with acute ischemic stroke were admitted to three hospitals between May 1999 and April 2000. The average NIHSS (National Institutes of Health Stroke Scale) was 8.2 (median 5). The length of hospital stay was $17.3 \pm 17.4$ (median 14) days. Two ${ }^{-}$ fifth of all patients were discharged to their homes, and $76.6 \%$ of them were discharged within 14 days. Another $2 /$ 5 patients were transferred to rehabilitation hospitals, and $62.1 \%$ of them were discharged within 21 days.

The reduction of length of hospital stay was achieved by the use of the clinical pathway and the inter-hospital cooperation.

(Received July 12, 2004 ; accepted August 2, 2004)

Key words : acute stroke, brain attack, management system, inter-hospital cooperation, clinical pathway Jpn J Neurosurg (Tokyo) $13: 762-769,2004$

熊本市立熊本市民病院神経内科 / $7862-8505$ 熊本市湖東 1-1-60（連絡先：橋本洋一郎〕

Address reprint requests to : Yoichiro Hashimoto, M.D., Department of Neurology of Kumamoto City Hospital, 1-1-60 Kotoh, Kumamoto-shi, Kumamoto 862-8505, Japan

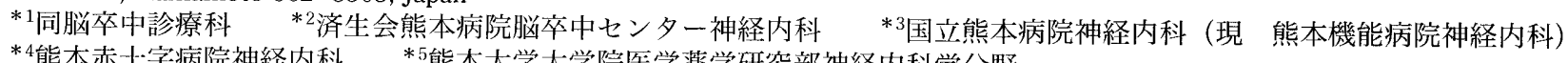

*4熊本赤十字病院神経内科 *5熊本大学大学院医学薬学研究部神経内科学分野 


\section{はじめに}

わが国の脳卒中診療システムは，急性期の治療法（血 栓溶解療法, 血管内治療, 脳保護療法など）の開発，脳 卒中専門病棟（stroke unit；SU）やクリニカルパスの導 入, 医療機関の病期別機能分化, 救急医療体制の整備, ガイドラインの導入, 脳卒中専門医制度など大きな変革 期を迎えている．このような中での脳卒中急性期の診療 態勢について述べる.

\section{Brain Attack}

\section{Brain Attack Campaign}

近年，脳卒中，特に脳梗塞に対する超急性期，急性期 の治療が進歩し, 特に発症 3 時間以内の脳梗塞に対する rt-PA（recombinant tissue-plasminogen activator）の有用 性が 1995 年に米国で示された。これより米国では，心 筋梗塞の「Heart Attack」に対して脳卒中を「Brain Attack」 とよび, “Stroke is an emergency" という Brain Attack Campaign を展開するとともに, 救急医療体制の整備が急 速に行われている．脳卒中と考えられる症状が出現した 場合には，救急車を呼び，すぐに脳卒中専門病院に搬送 し早期治療を受けるといった早期受診・早期治療の必要 性（Time is brain）が啓発されている，脳卒中専門病院 は 24 時間いつでも患者を受け入れ，かつ高度先進医療 を提供できる態勢を構築していくことが必要である。か かりつけ医や救急車からの依頼を断らないことから脳卒 中の治療が始まる.

\section{2 脳卒中緊急治療の鎖}

脳卒中超急性期では，(1)一般市民の脳卒中に関する知 識が平素より十分に浸透し，(2)ひとたび症状が出現した 場合にはバイスタンダーによる救急車の要請, (3)救急隊 によるトリアージで脳卒中専門病院への搬送, (4)救急部 で初期評価, 補助検査のオーダー, stroke team への通知, (5)stroke team に上る診断・治療の開始，(6) SU への収容 (Fig. 1）がスムーズに行われなければならない1)。心肺 蘇生と救急心血管治療のための国際ガイドライン 2000 (American Heart Association：AHA) では, 脳卒中治療に おける 7 つの“D”として, (1)Detection (発見), (2)Dispatch (出動), (3)Delivery（搬送), (4)Door (救急外来), (5Data (情報), (6Decision（決定), (7)Drug（薬剤）を挙げてい $ろ^{2)}$.

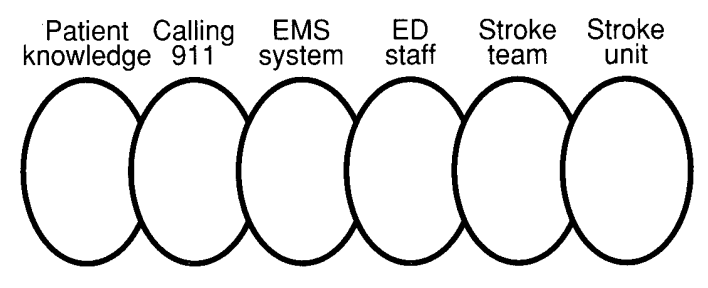

Fig. 1 Emergent stroke care and the chain of survival (Alberts, 2001) (1) $^{1}$

EMS : emergency medical services

ED : emergency department

\section{3 救急での受け入れ体制}

熊本市内で神経内科と脳神経外科がチームを組み, 脳 卒中急性期を 24 時間受け入れている施設は大学病院を 除くと熊本市民病院, 済生会熊本病院, 熊本赤十字病院, 熊本医療センター－(国立熊本病院）の 4 病院である。熊 本市（人口 66 万人）とその周辺を含む人口 100 万人が 診療圈となっており，熊本市の全救急車の $62 \%$ （2002 年）を受け入れている.さらに，熊本市周辺の救急車を 直接受け入れるとともに, 熊本県内の他の地域や宮崎県 の一部からの二次搬送の脳卒中症例も受け入れ， 1 年間 に 1,300 例以上の急性期虚血性脳血管障害を診療してい る (出血性脳血管障害は脳神経外科が担当)。2001 年 4 月２002 年 3 月に熊本市民病院と済生会熊本病院に発 症後 7 日以内に入院した脳梗塞患者の入院経路は, 外来 受診はそれぞれ $24 \%$ と $17 \%$, 救急車での搬送は $31 \%$ と $26 \%$, 紹介にて外来受診は $22 \%$ と $23 \%$, 紹介転送は $14 \%$ と $24 \%$ で救急車での直接来院は少なかった.

\section{脳卒中医療の問題点}

\section{1 わが国の医療制度}

2000 年に回復期リハビリテーション病棟（回復期リ 八）と介護保険が導入され, 回復期や維持期の脳卒中㟝 療態勢が整備され始めた。脳卒中急性期医療を担う急性 期病院は, (1)在院日数の短縮 (17 日未満), (2)紹介率の 向上 (30\%以上), (3)外来患者の抑制 (病床数の 1.5 倍未 満）が必要である。ささらに，(4) 24 時間にわたうて高度先 進医療を提供できる急性期の診療態勢の構築とともに, (5)病診連携の推進, (6)救急医療の推進を行わなければな らない.

\section{2 脳卒中急性期・回復期医療の問題点}

脳卒中急性期医療の問題点としては, (1) 1 つの施設に 多くの脳卒中患者が集まらないため大きなチームが組め ない零細な診療体制であること, (2)脸卒中專門医, 特に 
内科医が少ないこと, (3)地域, チーム, 病院, 医師ごと に診断・治療指針に違いがあること，(4)病院完結型（急 性期から回復期まで同一施設で治療）が多く入院期間が 長くなるためべッドが不足することなどがある。このた め多数の脳卒中患者を 24 時間いつでも受け入れられる 断らない医療と高度先進医療の両方を提供できる急性期 脳卒中治療施設は少ない.

\section{3] 神経内科診療}

一般病院神経内科の診療範囲として，(1)頭痛・めま い・しびれなどの外来診療, (2)脳卒中・けいれん・意識 障害などの救急神経疾患の診療, (3)神経難病, (4)痴呆の 診療, (5)リハビリテーション（以下，リハ）などと幅広 い. 少ない神経内科医でこれらの領域をカバーするため には，(1)脳神経外科と神経内科の連携，さらに多科・多 職種によるチーム医療, (2)かかりつけ医やリ八専門病院 との病診連携による地域完結型の診療態勢構築が必要と なる. 1995 1996 年に熊本市民病院に発症後 1 週間以内 に入院した脳梗塞 281 例 (平均年龄 71 歳, 紹介率 $65 \%$ ) の平均在院日数は 31 日で, 2 力月以上の長期入院 $8 \%$, 死亡 $4 \%$ で生存者の $39 \%$ が 29 病院へ転院していた ${ }^{6}$. ベッド不足が慢性化し, 紹介や救急車を断らざるをえな い状況であった。

\section{病診連携の推進}

\section{1 病診連携の必要性}

医療の高度・専門化あるいは機能分化が進む中で，(1) 良質かつ適切な医療の提供, (2)患者・家族と医療者の満 足度向上，(3)地域の医療資源の有効活用，(4)診療報酬な どの面から，かかりつけ医と急性期病院（あるいは専門 病院）との病䛦連携がますます必要となっている。脳卒 中診療はリ八の観点から, (1)急性期，(2)回復期，(3)維持 期の 3 つの病期に分けられ，(1)普段の健康管理と再発予 防を行うかかりつけ医，(2)超急性期や急性期の治療を行 う急性期病院，(3)回復期少八を行うリ八専門病院，(4)維 持期のリハ・ケアを行う療養型病院や老人保健施設など の 4 つのチームが必要である.この 4 つのチームによる 病診連携構築には多くの困難を伴う。

\section{2 急性期病院とリ八専門病院との連携}

急性期病院とリ八専門病院との連携を推進し，各種の 問題点を解決するために 1995 年から熊本市の東部地区 とその近郊の急性期病院の神経内科医・脳神経外科医 と，リ八専門病院のリ八医，さらにコメディカルを加え
て「脳血管疾患の障害を考える会」(年 2 回開催) を立 ち上げた ${ }^{13)}$ 。この中で急性期と回復期の連携について勉 強し，抢互いのデー夕を開示し意見交換を行ってきた。 さらに 2003 年に「回復・維持期り八を考元る会」(年 2 回開催）が立ち上げられた。

\section{3 急性期病院の成果}

3 施設の入院数と平均在院日数の経年的変化を Table 1 に示す，在院日数は退院者の入院日数より算出（1 泊 2 日の入院では 2 日として計算）している. 多くの急性 期脳卒中患者を 24 時間受け入れるためには, 在院日数 短縮による空床確保が必要である。クリニカルパス導入 とともにリ八専門病院との病診連携による地域完結型の 脳卒中診療態勢構築により入院患者の平均在院日数が急 速に低下し，一方で入院数が $2 \sim 3$ 倍に増加した。

1999 年 5 月〜 2000 年 4 月までの期間に厚生省健康科 学総合研究事業による脳梗塞急性期医療の実態に関する 研究が行われた ${ }^{17)}$. 156 施設の発症後 7 日以内の一過性 脳虚血発作を含む虚血性脳血管障害 16,922 例（平均年 齢 70.6 歳, 死亡率 $6.9 \%$ ）の平均在院日数は 35 日であっ た。この研究に加わった熊本市民病院と済生会熊本病院 に加えて，国立熊本病院の 3 施設で同じ期間に同じ対象 806 例（平均年齢 71.0 歳）が登録された ${ }^{7)}$. 10 ． 入院時の NIHSS（National Institute of Health Stroke Scale）は平均 $8.2 \pm 8.2$, 中央值 5 で，全国平均と同じであった，平均 在院日数は $17.3 \pm 17.4$ 日, 中央值が 14 日で急性期医療

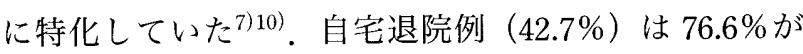
14 日間内で退院し，転院例 $(44.1 \%)$ は $62.1 \% か ゙ 21$ 日 内でリ八専門病院へ転院している ${ }^{10)}$.

急性期病院での在院日数延長要因として, 脳卒中の重 症度，合併症の存在，特に呼吸器感染症が挙げられる。 これは嚥下障害・栄養管理・感染対策などが大きく関 わってくる。ささらにリ八専門病院への予約から転院まで の待機期間も大きな要因である.

\section{4) リ八専門病院の成果}

急性期病院からみたリ八専門病院の以前の問題点とし て，(1)入院予約から転院までの待機期間が長いこと，(2) ハイリスク症例・問題症例の受け入れが悪いことなどが 挙げられる，連携リ八専門病院の熊本回生会病院では， 脳卒中発症から転院までの期間が 1992 年では $43.5 \pm$ 38.9 日であったものが，連携を積極的に始めた翌年の 1996 年は $28.1 \pm 16.6$ 日，さらに 1998 年は $23.5 \pm 18.0$ 日 と短縮された ${ }^{14)}$ 。平均在院日数は 1992 年が $260 \pm 202$ 日, 1996 年が $164 \pm 123$ 日, 1998 年が $117 \pm 77$ 日となり， 
Table 1 Number of all admitted patients and the length of hospital stay in neurology the Department in our three hospitals

\begin{tabular}{|c|c|c|c|c|c|c|}
\hline \multirow[t]{2}{*}{ Year } & \multicolumn{2}{|c|}{$\begin{array}{c}\text { Kumamoto City } \\
\text { Hospital }\end{array}$} & \multicolumn{2}{|c|}{$\begin{array}{c}\text { Saiseikai Kumamoto } \\
\text { Hospital }\end{array}$} & \multicolumn{2}{|c|}{$\begin{array}{c}\text { National Kumamoto } \\
\text { Hospital }\end{array}$} \\
\hline & $\mathrm{N}$ (cases) & $L$ (days) & $\mathrm{N}$ (cases) & L (days) & $\mathrm{N}$ (cases) & L (days) \\
\hline 1988 & 44 & 40.9 & - & & - & \\
\hline 1989 & 64 & 64.4 & - & & - & \\
\hline 1990 & 55 & 60.4 & - & & - & \\
\hline 1991 & 155 & 46.4 & - & & - & \\
\hline 1992 & 158 & 36.8 & - & & - & \\
\hline 1993 & 272 & 30.0 & - & & - & \\
\hline 1994 & 312 & 27.4 & - & & - & \\
\hline 1995 & 352 & 23.3 & 471 & 18.9 & - & \\
\hline 1996 & 367 & 22.9 & 510 & 16.8 & - & \\
\hline 1997 & 468 & 20.4 & 674 & 15.6 & - & \\
\hline 1998 & 543 & 15.3 & 705 & 13.8 & 147 & 21.6 \\
\hline 1999 & 607 & 14.9 & 812 & 13.9 & 197 & 21.8 \\
\hline 2000 & 620 & 13.9 & 1,044 & 12.2 & 238 & 25.2 \\
\hline 2001 & 579 & 13.8 & 1,041 & 12.2 & 324 & 17.1 \\
\hline 2002 & 617 & 13.9 & 1,154 & 12.0 & 413 & 16.4 \\
\hline
\end{tabular}

$\mathrm{N}$ : number admitted to hospital (stroke and non-stroke)

$\mathrm{L}$ : length of hospital stay

脳卒中入院数がそれぞれ 66 例, 139 例, 154 例と増加し た．回復期リ八病棟を持つリ八専門病院も同様な経緯で 在院日数が短縮し，発症から転院までは $2 \sim 3$ 週間以内 が多く, 平均在院日数も 70 90 日で多くの脳卒中症例 を受け入れることが可能となり，予約から 1 週間以内の 受け入机がほぼ確立されている。

\section{急性期医療}

\section{$1 \mathrm{SU}$ と SCU}

わが国で stroke care unit (SCU) の語を称する場合は, intensive な診療を行う脳卒中集中治療室を指すことが 多い. SUは, 病棟のハードウェアそのものは一般病棟 と同じで，一般病棟と異なる点は脳卒中についての専門 的知識を持つ専門家の学際的チームが脳卒中患者のケア を行うことである．脳卒中専門医を中心に多科・多職種 から構成されるチームが核となり, チームの脳卒中管理 指針に従って患者の包括的評価を行い，協調的に治療を 行う。SU は医療経済学的にみても費用は低く効率も高 い. NIHSS が 16 点までの中等症例だと集中治療室に入 院させても，一般病棟入院患者に比べて予後は変わらず 医療費だけが 4 倍かかるといゔ).

\section{SU の効果と改善点}

SU による治療では一般病棟による治療に比べ，発症
後 1 年間の短期死亡については約 $2 \sim 3$ 割死亡率が低下 し, 発症 5 年後の長期予後については約 $3 \sim 4$ 割の死亡 の危険率減少が示されている. 入院日数も一般病棟に比 べ 30\%短く,一方自宅退院の可能性も 1.4 1.9 倍に増や し発症 5 年後の在宅率もより高いことが確認されてい る.さらに発症 5 年後の日常生活動作 (activities of daily living; ADL) レベルが高く, より社会性の高い生活を営 み, 生活の質（quality of life；QOL）が高いことが示さ れている。

Indredavik ら ${ }^{11)}$ による検討では，発症 6 週間までに自 宅退院できるかどうかに最も関連していた要因は早期離 床と早期リ八の開始時期であった. Jørgensen $ら^{12)}$ による 検討では, 診断, 内科治療, リ八のプログラムが整って いる SU は,これらのプログラムがない一般病棟に比べ, 入院中の初期死亡率, 1 年後と 5 年後の死亡率が有意に 低く，この傾向は重症例で顕著であり SU では重症例が 最も恩恵に与る可能性が高いことが示された.Evans ら ${ }^{5)}$ による検討では，SUで治療を受けた症例は一般病棟で 治療を受けた症例に比べて，(1より多くのモニターで監 視されること，(2)酸素吸入を受ける割合が多いこと，(3) 解熱薬を投与される割合が多いこと，(4)誤燕対策がより 行われていること, (5)早期の栄養開始などの点が異なっ ていたとしている.さらに進行型脳梗塞, 呼吸器感染症, 脱水の症例が少なかった。誤苝対策, 早期の栄養開始, 合併症の頻度がそそれぞれ独立して転帰に影響していた。 


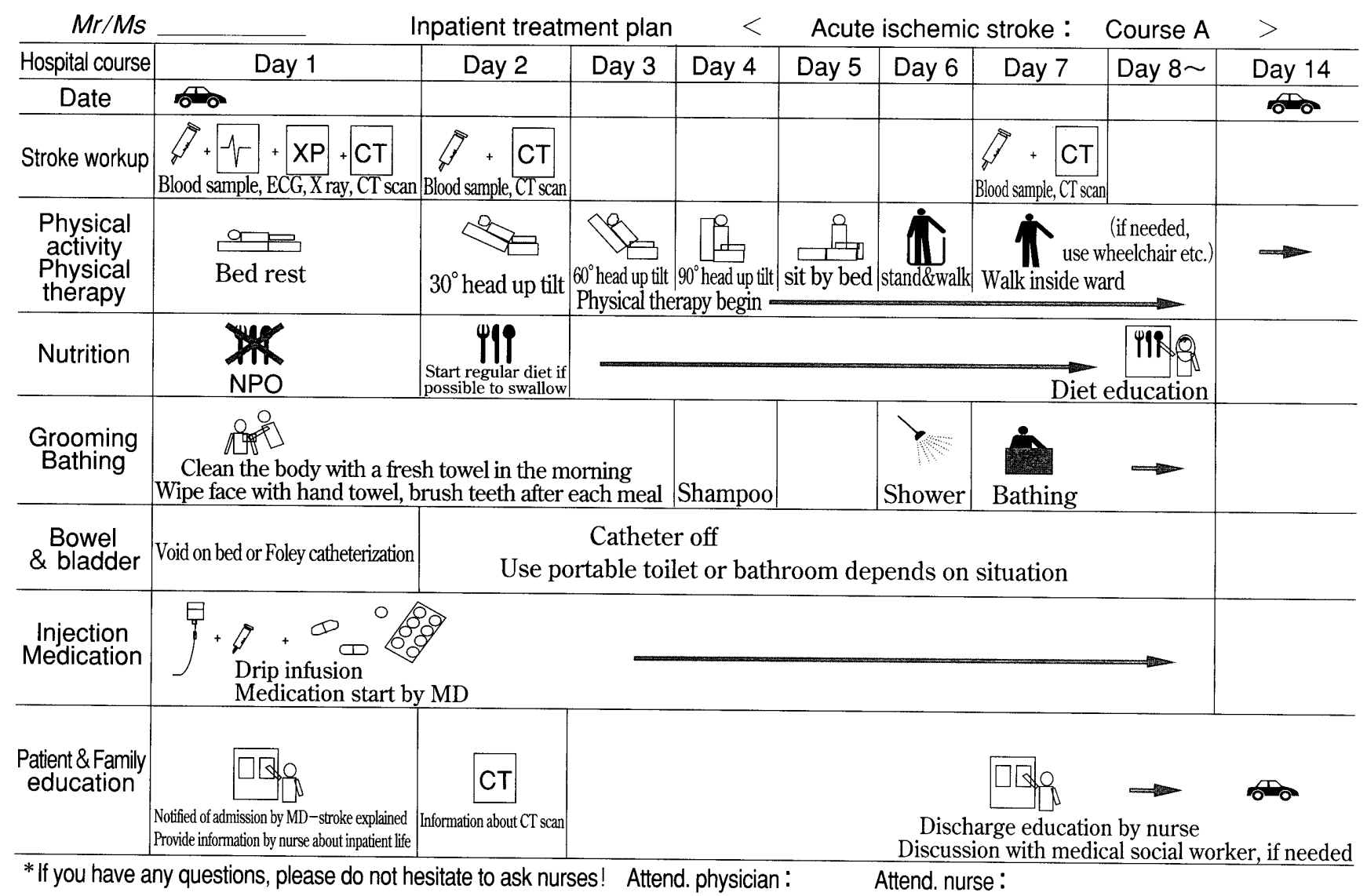

Fig. 2 Acute ischemic stroke clinical pathway (Course A for patient) ${ }^{18)}$

\section{3 急性期病院の診療態勢}

脳卒中患者が救急で病院に到着してからの対応時間 を NINDS (National Institute of Neurological Disorders and Stroke）が 1997 年に呈示し ${ }^{3)}$, AHA もガイドライン 2000 の中で踏襲している ${ }^{2)}$. (1)病院到着後 10 分以内に医 師による患者の初期評価，(2)15 分以内に stroke team の通知, (3)25 分以内に CT 開始, (4) 45 分以内に CT の診 断, 560 分以内に治療開始（血栓溶解療法), (63 時間 以内にモニターできるベッドへの収容を勧告してい $ろ^{3)}$.

さらに，血栓溶解療法の適応患者の場合には，(1)脳卒 中専門医が 15 分以内に対応, (2)脳神経外科専門医が 2 時間以内に対応するようなシステム作りを勧告してい る. CT のみならず神経超音波検查, MRI（拡散強調画 像を含む)・MRA，脳血管造影などを 24 時間稼働でき， 正確な診断と的確な治療方針を決定し血管内治療などを 含む高度先進医療を行う。

SU による脳卒中治療の核心は, 多職種が抢互い協力 してチーム医療を行うことである.クリニカルパスとは これらの協力をスムーズに行い, 質の高いチーム医療を 行うためのツールである. 当院では, 歩行コース (10日),
座位コース (10 日), ハイアップコース (14 日), A コー ス (14 日, Fig. $\left.{ }^{18)}\right)$, B コース (21日) の 5 つのコー スを運用している8).

\section{リハ専門病院とかかりつけ医}

\section{1リ八専門病院と回復期リ八病棟}

リ八専門病院では, 状態の安定した発症 $1 \sim 4$ 週目以 降の回復期り八を専門医が中心となったチームが包括的 に行う。リ八専門病院に入院した時点から最終的なゴー ルを推測し，在宅医療までを視野に入れて治療計画を立 てる。療養型病床群が利用可能で, リ八に関しては出来 高制となっている回復期リ八病棟の設置が 2000 年に可 能となり, 集中的な回復期り八が可能となった。患者・家 族満足度の高い病棟である。回復期リ八病棟は人口 10 万人あたり 50 床（全国で 6 万床）が必要といわれてい るが, ベッド数の地域差が大きいことが問題である，熊 本市とその周辺はり八専門病院の多くが回復期り八病棟 を開設しており，全体で 500 床以上存在しベッド数は充 足した状態である。リ八専門病院ではリハス夕ッフが多 いだけではなく，全身管理のできることが必要である. 


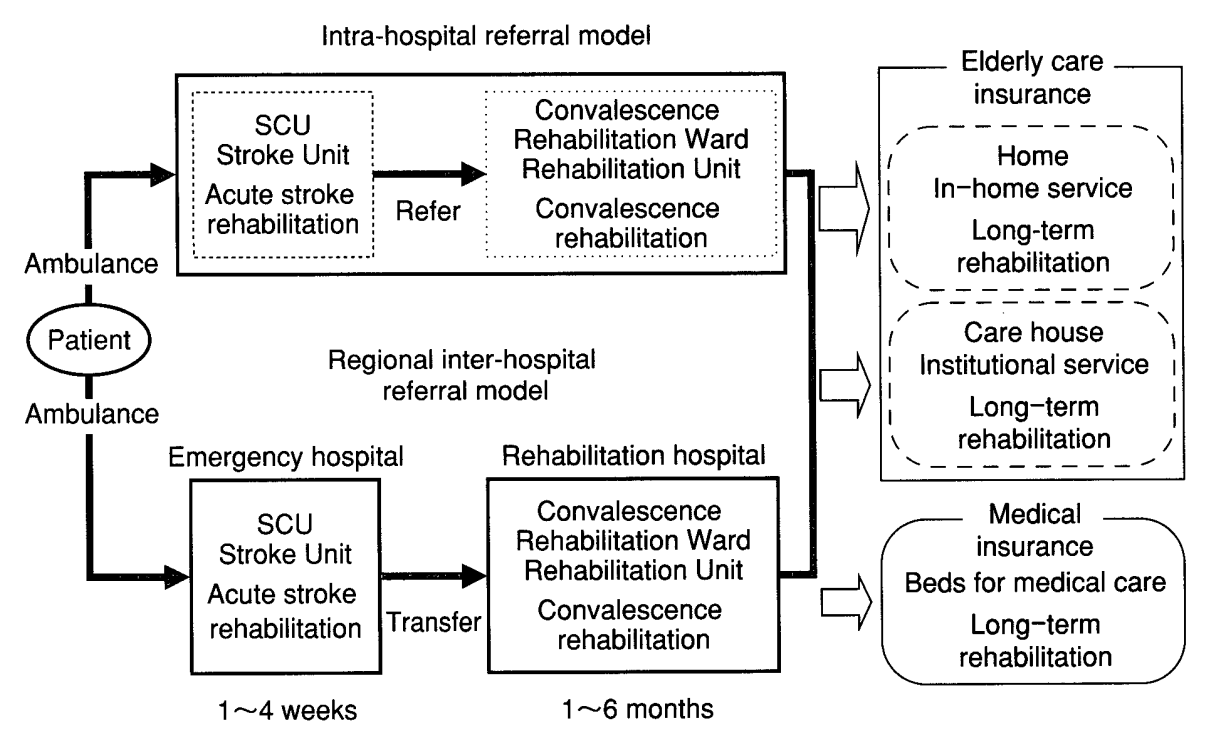

Fig. 3 The two models for stroke service ${ }^{18)}$

\section{2]特殊疾患療養病棟と障害者施設等一般病棟}

特殊疾患療養病棟（包括）は，主として長期にわたり 療養が必要な(1)重度の肢体不自由者, (2)脊髄損傷等の重 度の障害者, (3)重度の意識障害者, (4)筋ジストロフィー 患者, (5)神経難病を対象とした専門病棟であり, 2000 年 度から病室単位で算定できるようになった。 また一般病 棟 (出来高) で重度障害者を診療する障害者施設等一般 病棟もある．重度障害の症例はこれらの病棟での継続的 治療が必要である.

\section{3 かかりつけ医}

市民の望むかかりつけ医とは「病気や治療について丁 寧に説明し，どんな病気でも診察してくれて自分の手に 負えない時はふさわしい専門医を紹介してくれる近くの 医者」であり，また「病状が悪化した場合に適切な病院 に紹介してくれる ${ }^{16)}$ ，気軽に専門医を紹介してくれる， 24 時間対応してくれる」ということも求められている. 「24 時間の対応」とは「24 時間の安心」を提供してくれ ることであり，必ずしも 24 時間診察をしてくれること を指しているのではない，診察や電話相談ができない場 合, 連携している医師, 病院, 訪問看護師などが明示さ れていればよいのである，元来，主治医はかかりつけ医 であり, 急性期病院の専門医は主治医を介して自らの専 門的知識・技能・見識を患者のために使い，主治医から 指定のあった課題に対して責任を負う。かかりつけ医は 普段の健康管理（一次予防）や脳卒中の再発予防（二次 予防）を行い，脳卒中発症後も主治医としての役割を担 うことになる。

患者が「かかりつけ医」を選ぶとき医師に求める役割
と機能として, (1)近くにいること, (2)十分に説明してく れること，(3)どんな病気にでも対応してくれること，(4) いつでも診てくれること，(5)必要な時に京さわしい医師 を紹介してくれること（振り分け機能）の 5 点が挙げら れる ${ }^{15)}$.

\section{[4 地域リハビリテーション広域支援センター}

地域りハとは，障害を持つ人々や老人が住みなれたと ころで，そこに住む人々とともに一生安全に活き活きと した生活が送れるよう，医療・保健・福祉および生活に 関わるあらゆる人々がリ八の立場から行う活動のすべて を指す、「地域り八支援整備事業」を行うために熊本県に も，2000 年に熊本県地域リ八推進協議会が設置された。 熊本県地域リ八支援センターが県内に 1 力所設置され, 熊本地域り八支援協議会に業務委託がなされた。地域り 八広域支援センターは回復期や維持期のリ八を行うリハ 専門病院など 12 力所が指定されており, 地域り八の実 現に対して大きな期待がかけられている。 ただし，地域 リ八支援体制整備推進事業の実施状況では, 2003 年度で 実施都道府県は 42 , 地域り八広域支援センターの指定 は 36 都道府県の 222 施設である.

\section{病院完結型と地域完結型}

わが国の脳卒中診療の流れを Fig. 3 に示す918)．急性 期病院に入院した軽症患者は急性期治療を受けて自宅退 院し, 回復期リ八の適応のない最重症患者は急性期治療 から直接維持期ケアに移行する.回復期リハについては, 急性期以降もリ八を必要とする患者を対象に回復期り八 
病棟で集中的なリ八を行う。そして在宅医療への取り組 みも含めて維持期りハへのスムーズな移行を図る，急性 期チームから回復期チームへバトンタッチする時期は, 収支が合い，かつ急性期ベッド確保，急性期リ八から回 復期リハへの移行などの観点から, 現時点で発症から 2〜3 週間経過した時点が最適であろう。ただし, 病院や 地域の状況に応じて急性期病院からリ八専門病院へと転 院するパターン（Fig. 3 下段，地域完結型）と，同一病 院内で急性期病棟から回復期り八病棟へ転棟するパ夕ー ン（Fig. 3 上段，病院完結型）の 2 つが考えられる ${ }^{9)}$.

\section{おわりに}

24 時間にわたって高度先進医療を提供できる急性期 の診療態勢の構築とともに，急性期病院（脳神経外科医 や神経内科）とリ八専門病院（リ八医）との連携のさら なる強化が必要である，脳卒中の患者・家族にとって満 足できる医療態勢を地域全体で地域の害情に応じて構築 していくことが，さらに求められる時代である，脳卒中 診療を担う医療従事者は，(1)施設内に㧍ける学際的千一 么医療，(2)医療・福祉施設間の連携，(3)日本脳卒中協会 や患者会などの支援団体との連携により，患者と家族の QOL の改善を目指すことを忘れてはならない.

\section{文 献}

1) Alberts MJ: Treatment of acute ischemic stroke. J Cerebrovasc Dis 10 (Suppl 1) : 10-17, 2001.

2) American Heart Association: The era of reperfusion: Acute stroke. Guidelines 2000 for cardiopulmonary resuscitation and emergency cardiovascular care: International consensus on science. Circulation 102 (Suppl 1): I 204- I -216, 2000.

3) Bock BF: Response system for patients presenting with acute stroke. In Proceedings of a National Symposium on Rapid Identification and Treatment of Acute Stroke. Marler JR, Jones PW, Emr M, National Institute of Neurological Disorders and Stroke, National Institute of Health, NIH Publication (eds) : No. 97-4239, Bethesda, 1997, pp.55-56.

4) Briggs DE, Felberg RA, Malkoff MD, Bratina P, Grotta JC:
Should mild or moderate stroke patients be admitted to an intensive care unit? Stroke 32:871-876, 2001.

5) Evans A, Perez I, Harraf F, Melbourn A, Steadman J, Donaldson N, Kalra L: Can differences in management processes explain different outcomes between stroke unit and stroke-team care ? Lancet 358: 1586-1592, 2001.

6）橋本洋一郎, 寺崎修司, 池野幸一, 粕谷潤二, 内野 誠： 急性期脳梗塞の退院時転帰と病診連携の現況. 脳卒中 21：200-204， 1999

7）橋本洋一郎, 平野照之, 米原敏郎, 徳永 誠, 内野 誠: 脳卒中の診療体制 (1) 地域完結型. 脳卒中 $23: 364-369$, 2001.

8）橋本洋一郎，米原敏郎，稲富雄一郎，平野照之，内野 誠：脳卒中クリティカルパスの現状。脳卒中 $24: 460$ 467, 2002.

9）橋本洋一郎, 米原敏郎, 徳永 誠, 渡辺 進, 平野照之： 脳卒中における地域完結型リハビリテーション。リハ医 39: 416-427, 2002.

10）平野照之，橋本洋一郎，米原敏郎，徳永 誠，内野 誠： 地域完結型脳卒中診療態勢一熊本市神経内科関連 3 施設 の虚血性脳血管障害診療状況。脳卒中 24：201-207, 2002 .

11) Indredavik B, Bakke F, Slørdahl SA, Rokseth $R$, Håheim LL: Treatment in a combined acute and rehabilitation stroke unit: Which aspects are most important? Stroke 30: 917-923, 1999.

12) Jørgensen HS, Kammersgaard LP, Houth J, Nakayama H, Raaschou HO, Larsen K, Hübbe P, Olsen TS: Who benefits from treatment and rehabilitation in a stroke unit ?: A community-based study. Stroke 31:434-439, 2000.

13）古閑博明：地域完結型の脳卒中リハビリテーションシス テム。リ八医 38:812-817，2001.

14）村上洋一郎, 鬼木泰博, 三隅 博, 山隈維昭, 津留隆行, 山鹿異紀夫，大串 幹，橋本洋一郎，寺崎修司，米原敏 郎, 内野 誠：病病診連携と脳卒中リハビリテーション 成績. 臨床リ八 9:100-103，2000。

15）日本医師会：あなたの健康を守るために，日本医師会 編：国民健康読本. 日本医師会雑誌第 127 巻第 3 号付録, 2002 , pp. $28-31$.

16）田坂佳千：地域医療 - 在宅医療。社団法人日本内科学会 認定内科専門医会 (編)：内科臨床研修指導マニュアル。 日本内科学会, 2001, pp.128-138.

17）山口武典：脳梗塞急性期医療の実態に関する研究。平成 12 年度厚生科学研究費補助金健康科学総合研究事業研 究報告書, 2000, pp.4-11.

18）米原敏郎，稲富雄一郎，橋本洋一郎，平野照之，内野 誠：脳血管障害の医療手順。神経治療学 21: 155-166, 2004. 
要旨

脳卒中の診療態勢

$\begin{array}{lllllll}\text { 橋本洋一郎 } & \text { 米村 } & \text { 公伸 } & \text { 米原 } & \text { 敏郎 } & \text { 稲富雄一郎 } \\ \text { 徳永 誠 } & \text { 寺崎 } & \text { 修司 } & \text { 平野 } & \text { 照之 } & \text { 内野 誠 }\end{array}$

現在の医療は専門高度化し, 脳卒中を診療する医療機関の機能分化が進み, (1)かかつけ医, (2)急 性期病院, (3)リハビリテーション専門病院（リ八專門病院），(4)維持期のリハ・ケアを行う療養型病 院や老人保健施設などの 4 つのチームが必要である. 脳卒中治療は, Brain Attack としてかかりつけ 医からの紹介や救急車を断らないことから始まる.4 施設で脳神経外科と神経内科がチームを組み年 間約 1,300 例の虚血性脳血管障害急性期例を診療している. クリニカルパスの導入やリハ専門病院と の病診連携により，神経内科の平均在院日数が短縮できたために，少ない神経内科医で多くの症例を 受け入れることができる. 病診連携を軸とした地域完結型の脳卒中診療態勢構築が必要である. 